6. Ibid., p. 248 .

7. Ibid.

8. Norman S. Endler, "Beyond Citation Counts: Developing Research Profiles," Canadian Psychological Review 19:152-57 (1978).

9. Robert L. Hemreich and others, "Making It in Academic Psychology: Demographic and Personality Correlates of Attainment," Journal of Personality and Social Psychology 39:896-908 (Nov. 1980).

10. David Lewis Smith, Thomas Roche, and William Snizek, "Quality of Graduate Productivity in Sociology as Measured by the Citation Index: A Longitudinal Overview," Research in Higher Education 13:343-52 (1980).

11. Norman S. Endler, J. Philippe Rushton, and Henry L. Roediger III, "Productivity and Scholarly Impact (Citations) of British, Canadian and U.S. Departments of Psychology (1975)," American Psychologist 33:1064-82 (Dec. 1978).

12. Richard C. Anderson, Francis Narin, and Paul McAllister, "Publication Ratings versus Peer Ratings of Universities," Journal of the American Society for Information Science 29:91-103 (March 1978).

\title{
"Non-Depository" or Not: An Examination of the Designation of Non-Depository Titles in the Monthly Catalog of United States Government Publications
}

\section{Steven D. Zink}

The Monthly Catalog of United States Government Publications includes citations to various government publications not distributed to federal depository libraries by the Superintendent of Documents. For the most part these elusive publications represent titles which are produced in regional government printing facilities or by private contractors for a government agency. Although this distinction alone does not preclude distribution to depository libraries, the sheer lack of available copies has frequently resulted in only an entry in the Monthly Catalog. ${ }^{1}$ The sole distinction in the Monthly Catalog entries between these non-depository titles and the publications distributed by the Superintendent of Documents is that the depository publications are distinguishable by an item selection number and a black dot $(\bullet)$. The black dot simply indicates that the title was available for distribution to deposi- tory libraries and that, at the very least, regional depositories, as required by law, have a copy of the publication. The item selection number is even more crucial. The nearly 5,500 current item numbers represent all of the possible categories of publications available which selective depository libraries may elect to receive. For example, item number 17 represents the Yearbook of Agriculture. If a depository would select that item number, it would annually receive the Yearbook of Agriculture. Therefore a depository is capable of establishing a selective profile to suit users' needs much like a library would with an approval plan. Absence of these two elements indicates that the publication was not available for distribution to depository libraries. In an effort to have as complete a collection of government publications as possible, many depositories have sought to acquire some or all of these non-

Steven D. Zink is head, Government Publications Department, University of Nevada Library, Reno. The author wishes to thank library intern Jeanne Smith for her assistance in compiling the data used in this article. 
depository publications. For the past thirty years the most effortless means of obtaining these titles has been through a subscription to the Readex NonDepository Microprint Collection. Since 1953, through an agreement with the Library of Congress, the Readex Corporation has been locating and converting into microprint all government publications listed in the Monthly Catalog but not distributed through the Superintendent of Documents depository library program.

In late 1981 the Government Publications Department of the University of Nevada-Reno (a regional federal depository with a collection exceeding one million documents) undertook a study of this service by attempting to acquire these non-depository publications by means other than through subscription to the Readex Non-Depository Microprint Collection. ${ }^{2}$ One unexpected finding was that the placement of the item selection number and black dot data elements in the Monthly Catalog entries was far from completely accurate.

As a part of the analysis, the entries of the first seven issues of the Monthly Cata$\log$ for 1981 were monitored and requests were sent to the agencies authoring the publications for a copy of the nondepository titles listed. A request for each publication was also submitted to the $\mathrm{Li}$ brary of Congress' Documents Expediting Project using its special request service.

As solicited non-depository publications began to be received and subsequently shelved in the department, it became clear that many duplicated depository publications were already on the shelves. After careful checking and rechecking, it was discovered that of the 234 non-depository titles listed in the January through July 1981 Monthly Catalog, 94 (or 40 percent) of all the non-depository titles had in fact already been received through the depository library program. * Thus 40 percent of the titles designated in the Monthly Catalog as being non-depository (by the absence of the black dot) were, in fact, received on a depository basis (see table 1). The original number of erroneous citations was in actuality somewhat higher, but the Government Printing Office subsequently discovered five entries which were in error and noted that corrections should be made to the Monthly Cata$\log { }^{3}$

These errors in the Monthly Catalog have a number of serious consequences for the users of government publications. Perhaps the greatest concern connected with these omissions is the most obvious. Librarians in hundreds of depositories that do not subscribe to the Readex NonDepository Collection tell their patrons, when searching through the Monthly Cata$\log$, that the library could only possibly own those publications received on a depository basis and cited with a black dot. Hence, 40 percent of the time such an assertion for a complete depository would have been incorrect if the Monthly Catalogs covered in this study had been used. The patron would never have utilized the materials readily available on the library's shelves.

Consequences of these errors also afflict subscribers to the Readex Non-Depository Microprint Collection. The basis for inclusion of titles in the Readex NonDepository Collection is the absence of the black dot in the Monthly Catalog. When the black dot and item number are mistakenly deleted from an entry for a depository title, the patron will be led to believe that the library only has a copy of the publication in microprint, thus limiting its circulation and, in many instances, its usefulness to the patron. If the citation is taken from a Monthly Catalog of the past two or three years, the patron will be told that the library does not even own a microprint copy due to the current time lag in receipt of the Readex microprint.

The error in failing to accurately place the item number and black dot in the Monthly Catalog citation for depository titles is not without its fiscal considerations. Depository libraries purchasing the

*The depository status of certain titles was double-checked for accuracy by Roberta Scull against the holdings in the Government Documents Department at Louisiana State University. 
TABLE 1

ACCURACY OF NON-DEPOSITORY TITLE DESIGNATION IN THE MONTHLY CATALOG

\begin{tabular}{lcccc}
\hline \hline $\begin{array}{l}\text { Monthly } \\
\text { Catalogs }\end{array}$ & $\begin{array}{c}\text { Total Titles } \\
\text { Designated as } \\
\text { Non-Depository }\end{array}$ & $\begin{array}{c}\text { Titles } \\
\text { Actually } \\
\text { Non-Depository }\end{array}$ & $\begin{array}{c}\text { Titles } \\
\text { Actually } \\
\text { Depository }\end{array}$ & $\begin{array}{c}\text { Percent } \\
\begin{array}{c}\text { Erroneously } \\
\text { Not Designated } \\
\text { as Depository }\end{array}\end{array}$ \\
\hline Jan. 1981 & 6 & 4 & 2 & 33 \\
Feb. 1981 & 9 & 6 & 3 & 33 \\
March 1981 & 30 & 22 & 8 & 27 \\
April 1981 & 67 & 34 & 33 & 49 \\
May 1981 & 22 & 11 & 11 & 42 \\
June 1981 & 26 & 15 & 11 & 42 \\
July 1981 & 74 & 48 & 26 & 35 \\
Total & 234 & 140 & 94 & 40 \\
\hline
\end{tabular}

Readex Non-Depository Microprint Collection will receive and pay for those titles incorrectly indicated as non-depository in the Monthly Catalog. In times of tight budgets, such needless duplication of depository titles in microprint is disturbing. Based on the Readex subscription price of over $\$ 2,000$ for the non-depository publications in the 1980-81 fiscal year, a consistent 40 percent error rate would have resulted in over a $\$ 900$ expenditure for duplicated depository titles in microprint. Multiplying the cost of this unfortunate duplication by the number of depositories subscribing to the Readex NonDepository Collection makes these errors, collectively, very expensive.

One question that naturally emerges out of a study of non-depository publications is why there are today any non-depository publications in the Monthly Catalog. The basis for the traditional listing of nondepository publications was that only a single copy of each title, required for cataloging and classifying, was received by the Government Printing Office and thus distribution was impossible. ${ }^{4}$ The problems inherent in an agency supplying too few copies or even only one copy for distribution to depository libraries should not pose a problem today. Given the size of the current Government Printing Office's microfiche program (GPO estimates that it will distribute 53,000 different titles in microfiche in 1982), ${ }^{5}$ it stands to reason that when the Government Printing Office receives a copy of a title for cataloging and inclusion in the Monthly Catalog, it could make a microfiche copy for distribution to depositories. GPO has the capability to do this. Without question, current non-depository documents would receive more widespread use at far less expense than is presently the case. If all nondepository materials currently noted in the Monthly Catalog cannot be integrated into depository distribution, it is imperative that tighter quality control be instituted to curb the grievously high error rate observed in designating which materials are depository or non-depository. Not only are such errors costly, inconvenient, and a disservice to the documents-user community, but they undermine confidence in the reliability of the entire Monthly Catalog. ${ }^{6}$

\section{REFERENCES}

1. For an excellent history of the Monthly Catalog and legislation affecting depositories see: LeRoy C. Schwarzkopf, "The Monthly Catalog and Bibliographical Control of U.S. Government Publications," Drexel Library Quarterly 10:79-105 (Jan.-April 1974); LeRoy C. Schwarzkopf, "Regional Depositories in Peril: Or the Future Is Now," Drexel Library Quarterly 16, no.4:19-39 (Oct. 1980).

2. Steven D. Zink, "Analysis of Non-Depository Documents in the Government Publications Collection," Collection Building: Studies in the Development and Effective Use of Library Resources 4:39-43 (1982).

3. Monthly Catalog of United States Government Publications 1044:xii (Aug. 1981), 1045:xii (Sept. 1981), 1047:xiii (Nov.-Dec. 1981). 
4. Joe Morehead, Introduction to United States Public Documents (2d ed.; Littleton, Colo.: Libraries Unlimited, 1978), p.87.

5. U.S. Government Printing Office, "Comparison of Paper and Microfiche Distribution to Depositories" (distributed at Depository Library Council Meeting, Boston, April 1982).

6. There is a growing chorus of concern over a wide variety of inadequacies and inaccuracies in the Monthly Catalog. For published criticism see: W. Ellen Daniel and William C. Robinson, "Time Lag in the 1972 Monthly Catalog of United States Government Publications," Government Publications Review 3:113-21 (1976); Jon J. Harrison, "United States Congressional Publication Indexing: Statistical Comparisons between the CIS/Index and the Monthly Catalog," Government Publications Review 5:273-83 (1978); Carol Boast and Cheryl Nyberg, "The Monthly Catalog-July 1976-August 1977Observations, Evaluations, Congratulations," Government Publications Review 5:167-76 (1978); Joe Morehead, "A Status Report on the Monthly Catalog and 'Serials Supplement,' " Serials Librarian 4:131-41 (Winter 1979); Paul Axel-Lute, "Recent Developments in Federal Documents," Law Library Journal 71:250 (May 1978); John A. McGeachy, "The 'List of Special Materials' in the Monthly Catalog," Reference Services Review (forthcoming).

\section{SUPERIOR ADVANCED TECHNOLOGY TEXTS} From The Publishers of MACHINERY'S HANDBOOK

INDUSTRIAL ROBOTICS HANDBOOK

V. DANIEL HUNT

352 pp., May 1983, ISBN 0-8311-1148-8 \$32.50 (approx.)

\section{ROBOTICSSOURCEBOOKAND DICTIONARY}

DAVID F. TVER and ROGER W. BOLZ 304 pp., May 1983, ISBN 0-8311-1152-6 \$29.95 (approx.)

\section{PRODUCT DESIGN WITH PLASTICS}

JOSEPH. B. DYM

288 pp., January 1983, ISBN 0-8311-1141-0 \$27.95

\section{SYNFUELS HANDBOOK}

V. DANIEL HUNT

544 pp., January 1983, ISBN 0-8311-1144-5 $\$ 45.00$ (approx.)
SOLAR ENERGY DICTIONARY

1982 Winner-Best Professional and Scholarly

Publishing Book in Technology-Association of American Publishers

V. DANIEL HUNT

404 pp., 1982, ISBN 0-8311-1139-9 \$27.50

\section{ADVANCED WORK MEASUREMENT}

DELMAR W. KARGER and WALTON M. HANCOCK 321 pp., 1982, ISBN 0-8311-1140-2 \$34.95

\section{INGENIOUS MECHANISMS FOR DESIGNERS AND INVENTORS}

Four Volumes

...reference treatises on mechanica! movements unparalleled in scope and usefulness.

FRANKLIN D. JONES, HOLBROOK L. HORTON and JOHN A. NEWALL

4/Vols., ISBN 0-8311-1084-8 \$90.00 


\section{At Midwest Library Service, We Take The Team Approach To Assist Your Library}
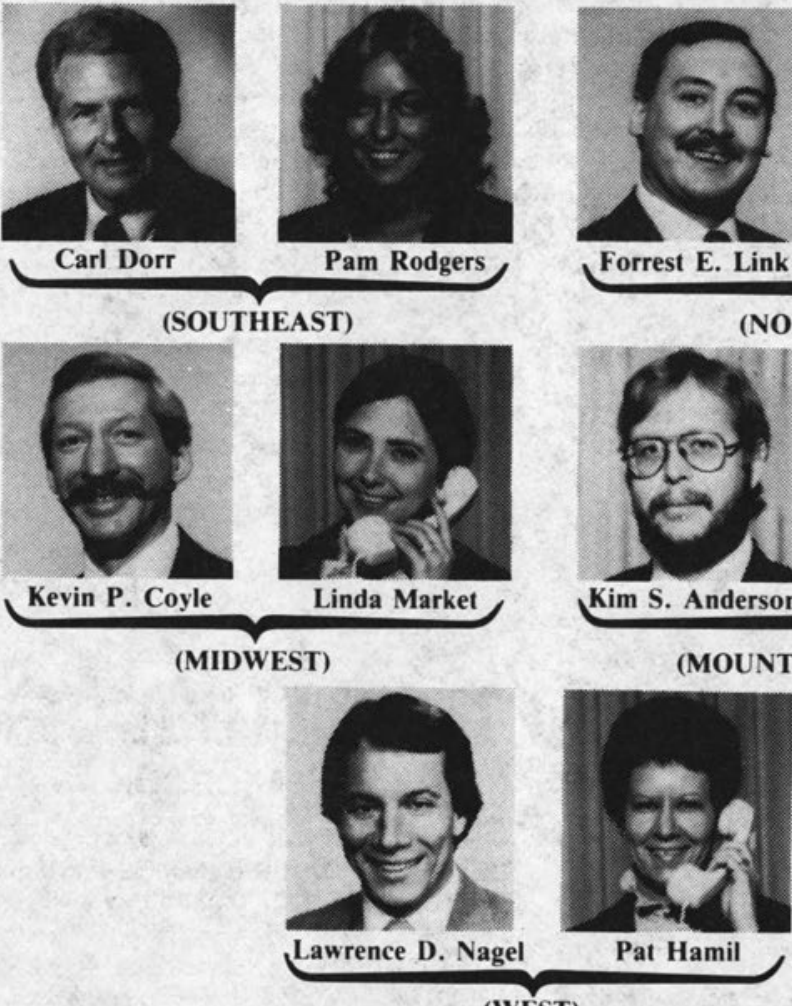

(WEST)

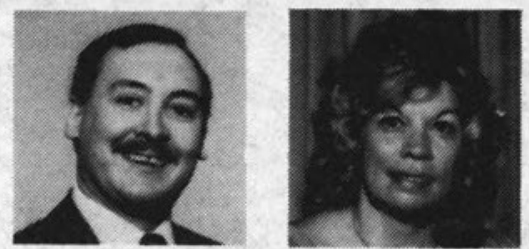

Forrest E. Link Carol Lehmkuhl

(NORTHEAST)

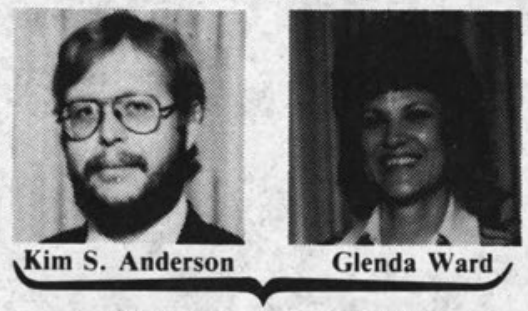

(MOUNTAIN PLAINS)

To best serve your needs, we have formed five problem-solving service teams to help take the hassle out of book-buying. Each team is composed of a Sales Representative in the field and a Customer Service Representative in our home office.

Once alerted by your phone call made on our Toll-Free WATS Line, 1-800-325-8833, (Missouri customers, please call COLLECT 0-314-739-3100) your problem-solving team, geographically assigned to your library, goes into

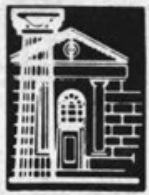

Midwest Library Service 11443 St. Charles Rock Road Bridgeton, Mo. 63044 action immediately.

It is another facet of Midwest Library Service's tradition of excellence.

May we have the privilege of serving your library?

"23 Years of Service To College and University Libraries" 